\title{
Diferensiasi Sunnah dan Hadis dalam Pandangan Ignaz Goldziher
}

\section{Sunnah and Hadith Differentiation According to Ignaz Goldziher's View}

\author{
Aramdhan Kodrat Permana \\ Sekolah Tinggi Agama Islam (STAI) Syamsul 'Ulum Gunungpuyuh \\ Sukabumi, Jawa Barat, Indonesia \\ aramdhankodratpermana14@gmail.com
}

\begin{abstract}
Abstrak
Hadis dan sunnah dipahami memiliki esensi yang sama. Namun fakta leksikal, terminologi dan historisnya berbeda. Penelitian ini bertujuan untuk membahas tentang diferensiasi tersebut dari perspektif Ignaz Goldziher dengan menggunakan metode penelitian kualitatif yang didasarkan pada library research dan perspektif hermeneutik. Alhasil, Goldziher memahami bahwa hadis adalah 'komunikasi' yang tidak terikat pada aspek keagamaan apa pun, tapi melihatnya sebagai refleksi umat Islam terhadap perkembangan keagaamannya, walaupun ia tidak menolak keberadaan matan dan sanad. Sedangkan sunnah didefinisikan sebagai sebuah pengulangan dari pandangan Arab kuno terhadap tradisi nenek moyang mereka yang kemudian diadopsi oleh Islam. Jadi perbedaan antara keduanya yaitu hadis pada dasarnya merupakan sebuah bentuk 'komunikasi' atau 'pembicaraan' yang disandarkan pada Rasulullah SAW, sedangkan sunnah hanya sebagai sebuah sikap aktual Nabi Muhammad SAW. Implikasinya, pemahaman Goldziher ini membawa dirinya pada skeptisisme hadis sebagai sumber kedua hukum Islam.
\end{abstract}

Kata Kunci: Hadis, Sunnah, Pandangan Ignaz Goldziher

\begin{abstract}
Hadith and sunnah seemed to have same significant. Contractively, they have a different meaning in lexical, terminological and historical aspect. This research aims to discuss about a sunnah and hadith differentiation in Ignaz Goldziher's view by use a qualitative research which is based on library research and hermeneutics perspective. As a result, He thought that hadith was an independent communication, but saw it as a Muslim's reflection on their religious development, even though he did not ignore the existence of matan and sanad. While the sunnah is defined as the repetition concept on Jahiliyyah's culture. So, the differences between them that hadith emphasizes the communication that base on Prophet Muhammad SAW, whereas sunnah more relating to actual attitude of Prophet. The implication of his view make him a strong sceptic on hadith as the second source of Islamic Law.
\end{abstract}

Kata Kunci: Hadith, Sunnah, Ignaz Goldziher's View 


\section{PENDAHULUAN}

Sebagai scientific term hadis dan sunnah seringkali dipandang sama, sinonim sekaligus berbeda. Tidak sedikit kemudian para ulama menyebut dua istilah tersebut untuk menunjukkan kepada entitas yang sama. Walau pada faktanya berbeda. Perbedaan itu pun setidaknya berangkat dari makna; makna literal/leksikal dan juga makna historis dua kata tersebut. Pun purlu dilihat bahwa perbedaan makna ini tidak sekedar untuk menegaskan garis demarkasi antara hadis ataupun sunnah. Akan tetapi perbedaan ini perlu diangkat untuk melihat implikasi dari dua signifikansi makna tersebut.

$\begin{array}{rcr}\text { Sampai } & \text { sejauh } & \text { ini } \\ \text { perkembangan } & \text { perdebatan } & \text { dua }\end{array}$
terma tersebut bukan hanya menjadi perhatian ulama Muslim, tetapi juga ulama non-Muslim, dalam hal ini orientalis. Dalam perkembangan keilmuan Islam, islamic Studies, hadis atau sunnah menjadi bagian penting mereka untuk menemukan kekuatan Islam di satu sisi dan kelemahan di sisi lain. Sehingga tidak sedikit dari mereka bersikap peyoratif terhadap Timur, dalam hal Islam, dan hadis.

Oleh sebab itu, maka dalam artikel singkat ini, penulis akan memaparkan pemaknaan terma hadis dan sunnah dari perspektif seorang orientalis Ignaz Goldziher, yang disebutkan oleh Musthafa A'dzami sebagaimana dikutip oleh Ya'qub (1995), sebagai orientalis yang pertama dengan karya monumentalnya,

Muhammaedanische Studien (Ya'qub, 1995). Walaupun akhirnya pendapat ini dibantah oleh A.J. Wensick dengan tulisannya, "The Importance of Tradition for Study of Islam", dalam The Moslem World II (1921), yang menegaskan bahwa Snouck Horgronje-lah yang pertama mengkaji hadis, bukan Goldziher. Fakta ini - menurut Wenscink - bisa dlihat dalam 
Revue Coloniale Internatonale (1886) dan Revue de I'Histore des Religions (1886) (Muslehuddin, 1997). Catatan yang lain - yang ditunjukan oleh Amin (2009) berbicara lain, bahwa Alois Sprenger-lah yang pertama kali menganalisis otentisitas literatur hadis.

Terlepas dari perdebatan tersebut bahwa Ignaz Goldziher diakui sebagai peletak dasar dasar skeptisisme terhadap hadis, bahkan buku hasil kajiaannya telah menjadi 'kitab suci' bagi para orientalis (Darmalaksana, 2004). Goldziher pun adalah orang yang pertama meneliti hadis dengan perspektif historis dan kritis yang sistematis (Amin, 2009). Pernyataan senada pun dilontarkan oleh Berg (2000) dengan mengatakan bahwa Ignaz-lah yang pertama kali memperkenalkan teori inovatif terkait dengan otentisitas hadis.
Lalu, hal yang sangat fundamental - dalam kajian hadis sebelum masuk pada otentisitas hadis adalah perbedaan term antara sunnah dan hadis (Rahman, 1984) Dengan demikian ada dua hal yang diharapkan dari penelitian singkat ini; memperkenalkan perbedaan kedua terma tesebut dalam perspektif orientalis, terutama Goldziher dan membongkar skeptisisme-nya dalam pembacaannya terhadap hadis.

\section{METODE PENELITIAN}

Metode Penelitian yang digunakan dalam artikel ketokohan ini adalah penelitian kualitatif yang menggunakan library research sebagai cakupan penelitiannya dan pendekatan hermeunetis sebagai perspektif untuk menganalisa pemikiran Ignaz Goldziher tentang diferensiasi sunah dan hadis. 
III. HASIL

DAN

\section{PEMBAHASAN}

\section{A. Biografi Singkat}

Goldziher

Goldziher, seorang

keturunan Yahudi yang lahir di Szekesfehervar, Hongaria, pada tanggal 22 Juni 1850 - dengan nama asli Yitzhaq Yehuda. Pada usianya yang kedua belas tahun ia sudah menulis suatu riasalah mengenai asal-usul waktu yang tepat bagi sembahyang orangorang Yahudi yang disebut Piyyuts. Sedangkan pada usianya yang keenam belas tahun, ia sudah mengikuti kuliah di Universitas Budapest. Dua tahun kemudian, ia lulus dari ujiannya di Calvinist Liceum Budapest. Dengan beasiswa dari negaranya, dia dikirim ke Jerman untuk belajar dengan Prof. Rodiger di Berlin tahun 1868, dengan H.L Fielscher dan G. Ebers di Leipzig pada tahun yang sama. Akhirnya, di bawah bimbingan Rodiger dia berhasil memperoleh gelar doktoral dalam usia 19 tahun (Darmalaksana, 2004).

Goldziher bukan hanya menguasai bahasa Ibrani, Hebrew, tetapi ia pun ahli dalam bahasa Semit. Hal ini bisa dilihat dari fakta sejarah bahwa pada tahun 1904 ia mejadi guru besar bahasa-bahasa Semit di Universitas Budapest. Pada tahun yang sama ia pun dianugerahi gelar doktoral dalam bidang kesusatsetraan oleh Universitas Cambridge dan Gelar LL.L dari Universitas Aberdeen Skotalandia. Sedangkan sebelumnya, pada tahun 1900 ia mengajar filsafat Yahudi di Jewish Seminary Budapest.

Adapun

karya

monumentalnya dalam studi Islam adalah Muhammedansiche Studien yang diterbitkan pada tahun 1890 . Buku tersebut secara umum membahas sejarah agama Islam dan terutama hadis dan sunnah. Adapun karya-karya lainnya 
mengenai studi Islam mencakup Die Zahiriten, Ihr Lhrsystem und Geschicte (Leipzig, 1884) yang membahas perkembangan sejarah aliran Zhahiriyyah, Vorlesungen über den Islam (Heidelberg, 1910) yang merupakan pengantar untuk memahami teologi dan hukum Islam, dan Madzahib al-Tafsir alIslami, yang membahas historisitas perkembangan penafsiran alQur'an, Zur Literargeschicte der Shi'a (1874). Selain studinya yang banyak tentang Islam Goldziher pun menelaah ketimuran yang secara khusus terkait dengan Arab; Beiträge zur Geschichte der Sprachgelehrsamkeit bei den Arabern (Vienna, 1871-1873) dan Abhandlungen zur arabischen Philologie (Leiden, 1896-1899). Adapun karyanya yang terkait dengan Bahasa Ibrani hanya satu, Der mythos bei den Hebräern und Seine Geschichtliche Entwickelung (Darmalaksana, 2004).
Dari semua karya ini apabila dilihat dari kacamata historisperiodik, maka dapat disimpulkan bahwa concern Goldziher terhadap Islam secara khusus terjadi di akhir hayatnya. Hal ini menunjukan bahwa pada awalnya, kajian keislaman bukan merupakan studi utama yang dan pertama kali ia geluti. Ia meninggal pada usia 71 , tepatnya pada tanggal 13 November 1921. Dengan karya monumentalnya terhadap Islam, maka ia dipertimbangkan sebagai The Founder of Islamic Studies di Eropa bersama Theodore Noldeke dan Christiaan Snouk Hurgronje.

\section{B. Diferensiasi Sunnah dan Hadis Menurut Goldziher}

Dalam diskursus Islam, diferensiasi sunnah dan hadis mendapat perhatian dan porsi khusus, terutama dalam kajian 'ulum al-Hadis. Fakta ini tentunya membuktikan bahwa ada perbedaan yang harus dijelaskan terlebih dahulu di antara keduanya, 
sunnah dan hadis. Namun ternyata para orientalis pun melakukan hal yang sama, mereka menganggap walaupun secara implisit - bahwa diferensiasi ini sungguh sangat penting dalam pembahasan hadis, khususnya yang membahas hadis secara intensif, tak terkecuali Goldziher (Goldziher, 1971). Bukan hanya karena definisi masing-masing tetapi kedua kata itulah yang akan menentukan langkah selanjutnya dalam penelitian, salah satunya otentisitas hadis. Karena tidak mungkin seseorang membahas tentang hadis dan sunnah lebih jauh tetapi ia tidak memiliki pemahaman yang particulary object dari kedua terma tersebut.

\section{Hadis Menurut Goldziher}

a. Perdebatan makna hadis secara etimologis

Kata hadis didefinisikan oleh para ulama dengan makna yang berbeda. Setidaknya ada dua golongan ulama yang mendefinisikan kata ini dengan makna yang berbeda. Pertama, para ulama yang mengartikan kata ini sebagai suatu komunikasi atau pembicaraan. Hal ini sebagaimana didefinisikan oleh Shalih (2007) dengan mengutip pernyataan Abdul Baqa' - bahwa hadis adalah isim dari tahdits yang berarti pembicaraan. Arti 'pembicaraan' ini telah dikenal oleh masyarakat Arab di zaman Jahiliyyah sejak mereka menyatakan "hari-hari mereka yang terkenal" dengan sebutan ahadits (buah pembicaraan). Al-Farra telah memahami arti ini ketika berpendapat bahwa mufrad kata ahadits adalah uhudutsah (buah pembicaraan). Lalu kata ahadits itu dijadikan jamak dari kata hadis (alDimasyqi, 2008).

Kedua, para ulama yang mendefinisikan kata hadis sebagai sesuatu yang baru, jadid, yang dekat, qarib, dan warta, khabar (Ash Shiddieqy, 1999) atau "kaun 
al-Syai ba'da in lam yakun" (adanya sesuatu setelah tidak adanya) (Ham, 2000) yang merupakan naqidl dari qadim (alMandzur, tth). Adapun yang dimaksudkan dengan baru adalah apa yang disandarkan kepada Nabi Muhammad saw, sedangkan yang qadim adalah Kitab Allah. Hal ini sebagaimana dinyatakan oleh Ibn Hajr al-'Asqalani bahwa yang dimaksud dengan hadis menurut pengertian syara' ialah apa yang disandarkan kepada Nabi saw, dan hal itu seakan-akan dimaksudkan sebagai bandingan al-Qur'an yang qadim.

Posisi Goldziher, pada konteks ini, berada di posisi keduanya, walaupun nanti ada perbedaan. Pertama-tama Goldziher menguraikan makna hadis secara leksikal sebagai sebuah kisah, komunikasi, yang berlaku bagi semua orang, bukan hanya Muslim. Kata tersebut pun bermakna sebuah infromasi historis, baik itu yang bersifat sekuler atau keagamaan, baik itu terjadi pada waktu yang telah lalu ataupun pada masa tertentu (Goldziher, 1971) Selanjutnya ia menjelaskan bahwa pada konteks sebuah legenda dan dongeng, kata 'hadis' juga diaplikasikan untuk subjek sebuah cerita. Oleh sebab itu pernyataan "menjadi suatu hadis" adalah menjadi contoh yang akan selalu diceritakan oleh generasi kemudian (Goldziher, 1971). Pada definisi awal ini terlihat bahwa dia nampak ingin memperluas wilayah komunikasi dan cakupan hadis atau mengembalikan makna itu pada meminjam istilah al-Ghazali ma'na wadl'iyyah-nya (al-Ghazali, 2010). Ia tidak ingin terlebih dahulu menghubungkannya dengan aspek keagamaan yang walaupun akhirnya pada konteks keislaman disandingkan pada aspek ini. Dalam hal ini dia seolah ingin mencari akar kata hadis sendiri yang sudah 
ter'lembaga'kan oleh suatu aspek, yaitu keagamaan. Maka tak salah jika Goldziher (1971) mengatakan bahwa hadis sudah mengalami pergeseran konteks makna kata atau perluasan medan semantis.

Jika dilihat dari posisi ini, Goldziher masuk pada kategori pertama. Akan tetapi jika melihat lebih ke dalam pembahasan makna kata hadis - yang meloncat sekitar 10 halaman - dengan menyinggung kata ahdatsa. Menurutnya kata ini adalah istilah yang biasa dipakai pada periode awal Islam untuk memperkenalkan sebuah inovasi yang tidak didasari kebiasaan masa lalu (Goldziher, 1971). Dia menyandarkan pendapat ini pada riwayat 'Aisyah, bahwa Rasulullah saw bersabda, "Man ahdatsa $f i$ amrina hadza ma laysa minhu fahuwa raddun". Maka dia pun menganggap bahwa pernyataan syarr al-Umur muhdatsatuha merupakan sebuah inovasi atau dengan kata lain bid'ah yang memang dilarang dalam koridor Islam.

Pernyataan ini dipertegas oleh Goldziher bahwa sinonim dari kata al-Bid'ah adalah muhdats atau hadath (Goldziher, 1971), yang menurutnya para ulama Islam memahaminya sebagai sesuatu yang dipraktekan tetapi tidak mempunyai relevansi dengan zaman dulu, yang dalam agama, dimaksudkan sebagai perilaku yang tidak dilakukan pada masa nabi - selama inovasi itu tidak memiliki dasar keagamaan (Goldziher, 1971).

Dalam hal ini Goldziher melakukan suatu perbedaan yang jelas, yaitu bagaimana ia membedakan kata hadis yang berasal dari kata hadatsa dengan kata yang merupakan keturunan dari kata ahdatsa. Hal ini sebenarnya bukan hal yang baru dan telah terjadi dalam diskursus wacana Islam, tetap hanya sebagai 'fakta' bahwa ternyata kata 
muhdats itu mempunyai arti yang saling bertolak belakang dengan sunnah secara definitif. Padahal kata hadis itu dalam pandangan ulama Islam disamakan dengan sunnah. Artinya bahwa kata hadis disatu sisi ditarik pada 'urf isti'mal yang positif dan muhdats atau ahdatsa pada wilayah yang negatif. b. Makna hadis secara termilonogis

Fakta bahwa hadis disandarkan secara positif oleh umat Islam lebih lanjut oleh Goldziher ditekankan ketika membahas hadis secara terminologis, bahwa kata hadis yang dipakai oleh umat Islam sebagai otoritas keberagamaan umat Islam yang tertinggi dikontraskan dengan kitab Allah, yang merupakan 'hadis' paling indah dan sempurna (Goldziher, 1971). Pernyataan hadis yang paling sempurna dan indah ini oleh Shalih (2007) diteliti, hasilnya bahwa banyak kitab Sunan yang mengungkapkan hal seperti itu, "Khair al-Hadits Kitabullah wa khair al-Huda huda Muhammad". Di sisi lain Goldziher pun 'mengamini' bahwa istilah ini diucapkan oleh Nabi sendiri, sebagaimana terdapat dalam suatu riwayat ketika Nabi ditanya oleh Abu Hurairah. "Abu Hurairah menanyakan kepada Rasulullah tentang siapa orang yang paling berbahagia pada hari kiamat. Rasululullah menjawab, "Saya telah mengharapkan, Abu Hurairah, bahwa engkaulah orang yang pertama menanyakan pada saya tentang pembicaraan, hadits, ini, selama mengamati bagaimana keinginanmu untuk untuk bertanya tentang hadits." (Shalih, 2007; Goldziher, 1971).

Goldizher disisi lain percaya bahwa hadis-hadis ini - yang dibawa pada daerah-daerah yang ditaklukan - adalah sesuatu yang bersangkutan dengan keagamaan dan praktek yang sah dan 
dikembangkan dibawah bimbingan

Nabi dan dihormati sebagai suatu norma untuk dunia Islam secara keseluruhan (Goldziher, 1971). Namun, pada proses hadis, dia mengatakan bahwa pengetahuan yang paling dekat dengan banyaknya hadis membawanya pada sikap (dengan hati-hati) skpetis daripada sikap percaya atau optimis kepada bahan-bahan yang dibawa dan dikompilasikan secara hati-hati, "Closer acquaintance with the vast stock of hadits induces skeptical rather than optimistic trust regarding the material brought together in the carefully compiled collections" (Goldziher, 1971). Maka wajar apabila Goldziher (1971) mengatakan bahwa ia tidak mungkin seoptimis atau sepercaya Dozy ketika berbicara tentang hadis, walaupun ia secara sadar mengetahui sejauh mana perkembangan hadis ini sebagai sebuah hasil dari perkembangan keagamaan, sejarah dan sosial Islam selama satu sampai dua abad.

Pada titik inilah kemungkinan kata skeptisisme yang disandarkan pada Goldziher. Bahwa setelah melihat fakta adanya berbagai proses yang lama dan dengan munculnya hadis yang banyak, ia mulai bersikap raguragu terhadap otentisitas hadis. Yang pada akhirnya, ia menyimpulkan bahwa hadis bukan sebuah dokumen sejarah masa pertumbuhan Islam, namun ia hanyalah sebuah refleksi dari sebuah kecenderungan yang muncul di sebuah komunitas selama perkembangan Islam, "The hadith will not serve as a document for the history of the infancy of Islam, but rather as a reflection of the tendencies which appeared in the community during the mature stages of its development" (Goldziher, 1971)

Hal ini senada dengan kritik Fuat Segzin terhadap Goldziher - 
sebagaimana dikutip oleh Kamaruddin - bahwa Goldziher tidak menerima sama sekali bahwa hadis nabi digunakan sebagai sebuah dokumentasi sejarah (Amin, 2009) Namun tidak dengan serta merta Goldziher menafikan tentang sanad, yang menjadi penyambung secara lisan suatu matan yang disampaikan.

c. Sanad dan Matan Hadis dalam pandangan Goldziher serta implikasinya

Setelah menjelaskan secara singkat apa yang dimaksud dengan hadis, Goldziher melanjutkan pembahasan pada struktur yang ada pada hadis, yang menurutnya terbagi menjadi dua - sama dengan pembagian ulama Islam - sanad dan matan. Sanad yang dimaksud adalah sebuah silsilah penyokong kebenaran, attestors, dari awal yang meriwayatkan sampai periwayat terakhir. Sedangkan matan itu adalah teks hadis. Secara sekilas pandangan ini sama dangan pandangan para ulama Islam. Namun disini Goldziher melangkah lebih jauh dengan mengatakan bahwa matan sudah dipakai pada pra-Islam dan bukan berasal dari hadis, yang biasanya menunjukan inti tulisan, written text (Goldziher, 1971).

Dia menyandarkan pendapat ini pada sebuah ungkapan perbandingan yang dikutip dari tulisan Labid dalam Mu'allaqa; wa jala al-suyulu 'an al-Thululi kaannaha / zubrun tujiddu وجلا السيول عن, mutunaha aqlamuha, dan الطلول كأنها ... زبرٌ تجد منونها أقلامها juga kalimat yang dikomentari oleh al-Ahways; dawarisu ka al- 'Ayni fi al-Mahraqi (al-Ashbahani, 2008). Hubungannya dengan matan, Goldziher menyatakan bahwa matan mendapatkan maknanya pada konteks ini, yaitu dua lafadz tadi yaitu al-'Ain dan al-Mutun, yang bermakna 'teks yang tertulis'. Pada waktu yang sama, 'ayn adalah istilah lama untuk teks yang 
disampaikan secara lisan, atau mulut ke mulut.

Menurut Goldziher (1971), pemilihan kata matan - walaupun dia mengakui belum mampu untuk menentukan kejadian awal kapan kata ini dipakai pertama kali untuk menggambarkan sebuah teks hadis dalam perbedaan yang tidak sesuai pada dokumen hadis yang disampaikan oleh silsilah authorities, sanad, yang mungkin disadari untuk menyangkal sebuah asumsi yang mengatakan bahwa dalam pandangan Muslim hadis secara orisinil bukanlah sesuatu yang ditulis dan hanya terbatas pada tradisi lisan (Goldziher, 1971). Pemahamannya ini berimplikasi pada pemahaman Goldziher terhadap penulisan hadis, yang menurutnya, merupakan metode pemeliharaan yang sudah sangat lama dan bahwa keengganan untuk memeliharanya dalam tulisan adalah melulu hasil dari kesadaran Muslim selanjutnya (Goldziher, 1971).

\section{Sunnah Menurut Goldziher}

Sunnah secara etimologis adalah al-Thariqah (Fairuzabadi, 2008) dan al-Lisan (al-Mandzur, tth). Ibn Mandzur mengatakan bahwa al-Sunnah adalah jalan yang telah ditempuh oleh orang-orang dahulu dan menjadi jalur bagi orang-orang setelahnya, dan ditambahkan dalam Mukhtar alShahah, baik itu bersifat terpuji ataupun tercela, sebagaimana dikatakan oleh al-Tahanuwi (alA'dzami, 1980) Muhammad Ajaj al-Khatib dalam hal ini mengutip sebuah syair dari Khalid bin Utbah al-Hudzaily, "Jangan kau cemaskan perjalanan yang kamu tempuh, yang pertama rela akan perjalanan adalah yang menempuhnya", فلا تجز عن من سيرة أنت سرنها * فأول راض سنة من يسير ها.

Adapun secara terminologis, A'dzami dan al-Khatib (1998) membagi tiga kelompok dengan 
pandangan berbeda; Pertama, dalam padangan Muhadditsin, sunnah adalah apa-apa yang nampak pada Rasulullah, baik itu qaul, fi'l, taqrir, atau shifah, baik itu sebelum menjadi nabi atau setelahnya, dan hal ini menurut A'dzami sama dengan definisi hadis. Kedua, para Ushuluyyin memandang sunnah hanya sebagai sesuatu yang disandarkan pada nabi an sich, dari perkataan, perbuatan dan taqrir. Ketiga, pendapat para al-Fuqaha yang menyatakan bahwa sunnah adalah segala sesuatu yang ditetapkan oleh Nabi tetapi tidak masuk dalam wilayah fardl atau wajib. (al-Khatib, 1998). Berbeda dengan A'dzami, Fazlur Rahman, melihat sunnah sebagai sebuah nilai sekaligus praktek ideal yang hendak dicontoh persis oleh generasi Muslim pada zaman lampau, dengan menafsirkan keteladanan Nabi bedasarkan kebutuhan-kebutuhan mereka yang baru dan materi-materi yang berkelanjutan dan progresif, berkemajuan (al-Khatib, 1998)

Pada kata ini, sunnah, Goldziher tidak membahas makna literal-leksikalnya. Namun ia lebih melihatnya dari persfektif historis. Ia memandang bahwa konsep sunnah berasal dari pengaruh dasar standar pembenahan sikap pada wilayah kehidupan invidual dan komunitas masyarakat Arab yang semenjak kedatangan Islam sunnah mencakup tata cara hidup dan masyarakat yang hubungannya dengan kehidupan agama Islam (Rahman, 1984). Namun menurut Goldziher, umat Islam melakukan 'penambahan cakupan sunnah' bukan didasarkan atas sebuah kebutuhan, need. Namun karena hal ini sudah ada pada masa paganis, Arab Jahilliyah. Bagi umat Islam, sunnah adalah segala sesuatu yang menerangkan tentang tradisi-tradisi, adat dan kebiasaan Arab dari para pendahulu, yang akhirnya kata ini masih dipakai 
oleh komunitas Arab (Goldziher, 1971).

Setelah menjalaskan bahwa sunnah ternyata mempunyai relevansi yang tidak terpisahkan dari masyarakat Arab Jahilliyah, paganis, Goldziher mencoba melihat definisi sunnah dari kacamata para sahabat (Amin, 2009) yang menurut mereka adalah segala sesuatu yang ditunjukan dan dipraktekan pada masa Nabi dan para sahabat awal. Mereka pun mengatakan bahwa ketaatan kepada sunnah bagi umat Islam sama hal nya dengan orang paganis Arab yang mengikuti sunnah para pendahulunya (Goldziher, 1971). Maka pada intinya bahwa konsep sunnah dalam Islam merupakan sebuah pengulangan atau imitasi dari pandangan Arab kuno. Hal ini sebagaimana yang dikatakan oleh A'dzami (1980) bahwa Goldziher menyebut sunnah dengan istilah istilah animis, jahiliyyah, yang kemudian dipakai oleh orang-orang Islam.

Jika dilihat secara historis menurut Goldziher, Madinah menjadi kota yang paling pertama menjaga hadis, sehingga muncullah istilah Dar al-Sunnah. Kota inilah yang paling bersemangat membela sunnah Nabi sekaligus melarang sebuah pembaharuan. Alasan lain mengapa 'istilah' tersebut melakat pada kota ini tiada lain - menurut Goldziher adalah karena di kota inilah sunnah diregulasikan secara formal. Pada perkembangannya, saat sunnah diabaikan di hampir seluruh dunia 'luar', kota Madinah menjadi penjaga utama dalam menjaga sunnah (Goldziher, 1971).

2. Diferensiasi Antara Hadis dan Sunnah Dalam Pandangan Goldziher

Hadis dimaknai oleh Goldziher sebagai sebuah refleksi dari sebuah kecenderungan yang muncul di sebuah komunitas selama perkembangan Islam. Ia 
menolak argumentasi para ulama yang mengatakan bahwa hadis adalah dokumentasi sejarah. Adapun sunnah menurutnya mempunyai relevansi historis dengan orang Arab paganis - atau dalam bahasa A'dzami disebut sebagai - animis. Berangkat dari hal ini, Goldziher memilih untuk membedakan makna dan signifikansi dua kata tersebut.

Walaupun memang beberapa usaha telah dilakukan untuk membedakan definisi diantara keduanya dan di pihak lain ada yang menyamakannya (Ismail, 1988), menurut Goldziher keduaduanya berbeda, they are by no means the same. Hal ini bisa dlihat dari fakta sejarah perkembangan terminologi kedua kata tersebut (Goldziher, 1971), sebagaimana yang telah diulas pada pembahasa masing-masing istilah.

Perbedaannya adalah bahwa hadis adalah sebuah bentuk komunikasi lisan yang turun temurun dari Nabi Muhammad saw, sedangkan sunnah merupakan sesuatu yang berlaku atau dipakai oleh komunitas Muslim lama yang menunjukan pada aspek keagamaan dan sebuah bentuk hukum, tanpa memandang ada atau tidaknya tradisi lisan (Goldziher, 1971). Sebuah norma - tutur Goldziher - yang mengandung hadis secara natural bisa disebut sunnah, tetapi belum tentu sunnah itu harus bersesuaian dengan hadis yang merupakan pendukung sunnah. Atau dengan kata lain sangat mungkin bahwa suatu konten hadis mungkin bertentangan dengan sunnah, yang Goldziher istilah dengan, jus consuetudinis, (Goldziher, 1971) yang menurut Wahyudin inilah perbedaan fundamental antara hadis dan sunnah yang diosodorkan oleh Goldziher. Ia pun mengatakan bahwa inilah yang menjadikan kerangka dasar pandangan Goldziher tentang otentisitas hadis. 
Namun jika memang bahwa hadis itu sunnah atau antara sebuah tradisi lisan dan tradisi atau suatu adat dalam bentuk perilaku bertentangan dengan, lantas mengapa Goldziher mangatakan bahwa hadis adalah dokumentasi tentang sunnah? (Goldziher, 1991). Jawaban ini sebenarnya telah dijelaskan olehnya secara implisit dengan pengakuannya terhadap muatan hadis, yaitu sanad dan matan. Goldziher menyatakan;

"Tindakan dan keputusan dipandang benar dan keabsahannya pun diterima apabila mata rantai perawian yang bisa dipertanggungjawabkan pada akhirnya bisa memberikan pengakuan bahwa sетиa itu memang sesuai dengan kehendak Nabi saw. Pada kekuatan hadis yang seperti itulah kebiasaankebiasaan tertentu dalam ibadah dan hukum diakui sebagai tata cara kaum mukminin Islam pertama yang dipandang berwenang, dan telah pula dipraktikan di bawah kesaksian Nabi pribadi. Pada kekuatan hadis seperti itulah kebiasaan-kebiasaan tertentu dalam ibadah dan hukum diakui sebagai tata cara kaum mukminin Islam yang pertama yang dipandang berwenang, dan telah pula dipraktikan di bahwa kesaksian Nabi pribadi" (Goldziher, 1991).

\section{PENUTUP}

'Skeptisisme' yang disandingkan pada diri Ignaz Goldziher ternyata memiliki relevansinya ketika ia dengan terus terang mengatakan bahwa 'proses pengumpulan hadis' ini telah membuatnya bersikap skeptis. Maka, bisa dikatakan bahwa skeptisisme Goldziher lahir setelah ia melakukan analisis terhadap proses hadis, bukan karena ia sudah meragukan hadis sebelum penelitian terhadapnya.

Adapun pandangannya terhadap hadis, ia menjabarkannya 
menjadi dua kategori. Pertama, ia merupakan sebuah 'komunikasi' atau pembicaraan yang secara wadl'iyyah tidak terikat pada aspek keagamaan apa pun. Sehingga menurutnya hadis yang didefinisikan oleh umat Islam tiada lain merupakan perubahan konteks makna kata hadis. Goldziher pun menekankan bahwa hadis bukanlah dokumentasi sejarah sebagaimana dikatakan oleh Fuat Segzin - namun ia nampak sebagai sebuah refleksi umat Islam terhadap perkembangan keagaaman Islam. Akan tetapi ia tidak menafikan akan adanya matan dan sanad pada hadis, sebagai dua unsur yang tidak bisa dipisahkan dari hadis. Kedua, ia 'membahas' secara sempit bahwa ternyata kata ahdatsa itu bertendensi negatif dalam 'urf isti'mal agama Islam yang berarti sebuah pembaharuan atau bid'ah sebagaimana disinonimkan oleh Goldziher, yang dalam bentuk kata benda disebut muhdatsatun. Akan tetapi Goldziher dalam hal ini tidak mencampuradukkannya dengan pembahasan istilah hadis itu sendiri.

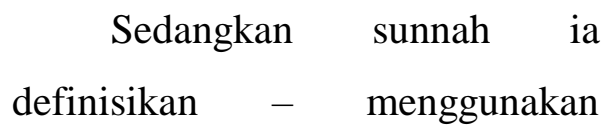
perspektif historis - sebagai sebuah pengulangan atau imitasi dari pandangan Arab kuno terhadap tradisi nenek moyang mereka yang kemudian diadopsi oleh Islam. Adapun perbedaan antara sunnah dan hadis - sebagaimana dikatakan oleh Goldziher - bahwa hadis pada dasarnya merupakan sebuah bentuk 'komunikasi' atau 'pembicaraan' yang disandarkan pada Rasulullah sedangkan sunnah hanya sebagai sebuah sikap aktual. Sehingga Goldziher mengatakan bahwa ada kemungkinan suatu konten hadis bertentangan dengan sunnah, begitu pun sebaliknya, terkadang dalam suatu norma tertentu hal itu mencakup sunnah, tetapi belum 
tentu ditemukan hadis yang akan

menguatkan sunnah tersebut.

\section{DAFTAR PUSTAKA}

Al-A'dzami, M. (1980). Dirasat fi al-Hadits al-Nabawi; Tarikh Tadwinih. Beirut: al-Maktab al-Islamiy.

Al-Ashbahani, A. F. (2008). al-Aghani. DVD ROM al-Maktabah al-Syamilah.

Al-Dimasyqi, A. (2008). Qawaid al-Tahdits min Funun Mushtalah al-Hadits. DVD ROM al-Maktabah al-Syamilah.

Al-Ghazali, (2010). al-Mustashfa. Beirut: Dar al-Kutub al-'Ilmiyyah.

Al-Khatib, M. A. (1998). Ushul al-Hadits: Pokok Pokok Ilmu Hadits terj. Qodirun dan Ahmad Musyafiq. Jakarta: Gaya Media Pratama,

Al-Mandzur, (tth). Lisan al- 'Arab. Beirut: Dar Mashadir.

Amin, K. (2009). Menguji Kembali Keakuratan Metode Kritik Hadis. Jakarta Selatan: Hikmah,

Ash Shiddieqy, H. (1999). Sejarah dan Pengantar Ilmu Hadis. Semarang: Pustakan Rizki Putra.

Berg, H. (2000). The Development of Exegesis in Early Islam. Cornwall: Padstwom.

Darmalaksana, W. (2004). Hadis di Mata Orientalis: Telaah atas Pandangan Ignaz Goldziher dan Joseph Schacht. Bandung: Benang Merah Press.

Fairuzabadi, (2008). al-Qamus al-Muhith. DVD ROM al-Maktabah alSyamilah.

Goldziher, I. (1971) Madzhab Tafsir Dari Klasik Hingga Modern terj. M Alaika Salamullah (dkk.), Yogyakarta: elSAQ Press. 
. (1971). Muslim Studies terj. C.R. Barber dan S.M. London: Ruskin House Museum Street.

. (1877). Mythology Among The Hebrews and Its Historical Development terj. Russell Martineau. London: Longmas.

. (1991). Pengantar Teologi dan Hukum Islam terj. Andras dan Ruth Hamori. Jakarta: INIS.

. (2008). The Zahiris: Their Doctrine and Their History A Contribution to The History of Islamic Theology terj. Wolfgang Behn. Leiden: Brill.

Ham, M. (2000). Evolusi Konsep Sunnah; Implikasinya pada Perkembangan Hukum Islam. Semarang: IAIN Walisongo Press.

Ismail, M. S. (1988). Kaedah Kesahihan Sanad Hadis. Jakarta: Bulan Bintang.

Muslehuddin, M. (1997). Filsafat Hukum Islam dan Pemikiran Orientalis Studi Perbandingan Sistem Hukum Islam. terj, Yudian Wahyudi Asmin. Yogyakarta: Tiara Wacana.

Rahman, F. (1984). Membukan Pintu Ijtihad terj. Anas Mahyuddin. Bandung: Pustaka.

Shalih, S. (2007). Membahas Ilmu-Ilmu Hadis terj. Tim pustaka Firdaus. Jakarta: Pustaka Firdaus.

Ya'qub, Ali Musthafa. (1995). Kritik Hadis. Jakarta: Pustaka Firdaus. 